\title{
Preliminary findings on the relationship between gender, FTO rs9939609, leptin \& ghrelin levels and eating behaviours of adults
}

DUYGU AĞAGÜNDÜZ ( $\nabla$ duyguturkozu@gazi.edu.tr)

Gazi Universitesi https://orcid.org/0000-0003-0010-0012

Makbule GEZMEN-KARADAĞ

Gazi Universitesi

\section{Research}

Keywords: FTO, rs9939609, eating behaviour, TFEQ, leptin, ghrelin

Posted Date: June 17th, 2020

DOI: https://doi.org/10.21203/rs.3.rs-35478/v1

License: (c) (i) This work is licensed under a Creative Commons Attribution 4.0 International License.

Read Full License 


\section{Abstract \\ BACKGROUND}

The single nucleotide polymorphisms (SNPs) and mutations in the first intron of the fat mass and obesity-associated (FTO) gene (rs9939609) have been reported to be associated with obesity and eating behaviour in children and adults in widespread populations. This study was conducted to determine the relationship between FTO gene polymorphism and eating behaviour in adults with different genders.

\section{METHODS}

The present study included 200 participants (100 males, 100 females) aged 18-65 years, who were genotyped for FTO gene (rs9939609) polymorphism. Eating behaviour were evaluated via revised 18-item of the three-factor eating questionnaire(TFEQ-R18). Serum leptin\& ghrelin were analysed. ABI TaqMan SNP Genotyping Assays (LightCycler 480 System, Roche) was used to determine the intronic FTO gene rs9939609 (T/A) SNPs.

\section{RESULTS}

Total $68.4 \%$ of individuals with AA genotype which was homozygote risky genotype for obesity were female and $31.6 \%$ were male $(p<0.05)$. When eating behaviour scores of individuals according to genders, the difference between the cognitive restraint scores (M:16.7 \pm 2.74 vs. F:16.1 $\pm 2.34 ; p<0.05$ ) and emotional eating score(M:10.2 \pm 2.26 vs. $F: 8.5 \pm 2.84)$ was statistically significant $(p<0.05)$. However, there was no statistically significant difference between the total scores of the TFEQ-R18 of males and females ( $p>0.05$ ). When examining eating behaviour scores of individuals according to genotypes; it was found that no statistically significant difference between the sub-dimensions and total scores of TFEQ-R18. However, total score of TFEQ-R18 was negatively associated with the serum leptin in females with AA genotype $(p<0.05)$, and positively associated with the serum ghrelin levels in males with TT genotype $(\mathrm{p}<0.05)$.

\section{CONCLUSION}

It was determined that eating behaviours in adults differed by gender rather than genotypes of FTO gene (rs9939609) polymorphism and gender was important factor for eating behaviour related to FTO gene rs9939609 genotypes in association with serum leptin-ghrelin level.

\section{Background}


Obesity is affected by genetic, environmental and many physiological factors. Different responses of individuals to environmental changes and individual's body weight differences emphasize the role of genetic factors in this variation $[1,2]$. Based on studies on twins, the effect of obesity-related genetic factors is estimated to be between $40-70 \%$ [1].

Obesity phenotypes and genome-wide association studies (GWAS) of transgenic mice have led to discovery of new obesity genes. By the year 2013, obesity-associated 835 gene loci and 317 single nucleotide polymorphisms (SNPs) were discovered $[3,4]$. The gene encoding the FTO protein among this gene cohort was thought to be the first and most potent gene to be associated with obesity in different populations [5].

In many GWAS studies, variations occurred in the FTO gene (16q12.2) have been shown to be associated with obesity [6, 7]. In particular, it was reported that SNPs (rs9939609) and mutations that occurring the first intron of the FTO gene were associated with obesity in children and adult populations[8]. In the literature, the "A allele" in the FTO gene rs9939609 SNP is defined as the risk allele for obesity. Supporting to this, a study reported that the body weights of those who were homozygous for the risk allele (AA genotype) were 3-4 kg more and the obesity risk was 1.67 times higher [5]. Although the effects of FTO gene SNPs on obesity have been demonstrated in different age groups, races and genders, the mechanisms that explain this still remain unclear.

Expression of the FTO gene in the hypothalamic nucleus which plays a key role in energy metabolism that suggests that the FTO gene contributes to energy homeostasis[6]. It was reported that rs9939609 A allele was more common in individuals with eating disorders such as bulimia nervosa and anorexia nervosa [9] and had higher emotional uncontrolled eating scores and this might lead to obstructive eating behaviours $[10,11]$. Consistent with this, a study reported that the food intake of FTO rs9939609 risk allele carriers was affected and those who carried $A$ allele and AA genotype were getting respectively 505 and $1231 \mathrm{kj}$ more energy compared to TT homozygous carriers [12].

In the explanation of the effect mechanism of FTO gene polymorphisms on food/energy intake, the effects on some appetite hormones such as serum leptin and ghrelin are mostly emphasized. It was reported that genetic variations in the loci of this gene (rs9939609, rs17817449 and rs142085) contributed to the etiology of obesity by affecting the level of plasma leptin, ghrelin and causing insulin resistance $[13,14]$.

The relationship between FTO gene polymorphism, serum leptin, and ghrelin levels and eating behaviour in adults was evaluated in this study.

\section{Methods}

\section{Subjects}


This study is conducted on 100 males and 100 females, a total of 200 volunteered (95\% power) Turkish adults (18-65 years) who had different body mass index (BMI) values. The homogeneity of the samples in terms of age, gender and BMI was cared. Those who are consanguineous, those of different ethnic origin, those with cancer, liver and kidney failure, hypothyroidism and hyperthyroidism, Type 2 diabetes, those who had a psychological disease diagnosed by a physician and receiving a medical treatment for this, those with alcohol and substance addiction, those who are pregnant and breastfeeding, and individuals about whom there are concerns in adapting to the research were not included in the research.

To carry out this study, ethics committee approval (24074710-020/01 numbered and 02/13/2017 dated) was obtained from Gazi University Clinical Research Ethics Committee. Individuals have been explained the purpose and method of the study, and individuals who accepted to participate in the study were signed a voluntary consent form in accordance with the Helsinki Declaration (World Medical Association).

\section{Instruments}

\section{Questionnaire form}

Within the scope of the research demographic characteristics of the individuals were determined using face-to-face interview technique with a questionnaire form.

\section{Three-factor eating questionnaire (TFEQ)}

In the evaluation of eating behaviour of individuals, the revised 18-item of the three-factor eating questionnaire (TFEQ) was used. With this questionnaire, it is possible to measure the degree of the cognitive restraint of the people (the cognitive restraint of eating in order to control body weight or to increase body weight loss), the uncontrolled eating levels (loss of control of excess food intake and predisposition to eat more than normal, depending on individual considerations against hunger); and the degree of eating (inadequacy against emotional symptoms) when they are emotional. The questionnaire was first created in 1985 by Stunkard and Messick as 51 questions. In its original form, it measures three factors which are " cognitive restraint of eating ", " disinhibition " and "hunger"[15]. After the validity and reliability studies of the 51 -item questionnaire were performed in various populations, the concerns about the factor structure and stability have arisen. Karlsson et al.(2000) determined that the factor structure of the original survey was non-repeatable in the middle-aged obese males and females[16]. In this context, they revised the questionnaire by taking the psychometric analysis as a base and gave its last shape with 18 questions. The revised 18-item form measures "the degree of cognitive restraint", "the levels of uncontrolled eating", and "the degree of emotinal eating"[16]. Although the questionnaire was developed on obese individuals, it was reported to be applicable in other groups and populations. The Turkish validity and reliability of the revised 18-items and three sub-dimensions forms was performed by Kıraç et al. (2015)[17]. Kıraç et al. (2015) found that the Three-Factor Eating Questionnaire also measured the sensitivity to hunger in addition to these three factors[17]. 


\section{Biochemical measurements}

Morning blood samples of individuals were taken after one night (10-12 hours) fasting. Leptin and ghrelin analysis in serum samples were performed by Enzyme-Linked Immunosorbent Assay (ELISA) method using Human Leptin-LEP ELISA Kit (CUSABIO®) and Human Ghrelin-GHRL ELISA Kit (CUSABIO®). The results obtained were expressed in $\mathrm{ng} / \mathrm{mL}$ for leptin and in $\mathrm{pg} / \mathrm{mL}$ for total ghrelin.

\section{DNA extraction and genotyping}

For the genetic analysis, $3 \mathrm{~mL}$ of blood was collected from the individuals into tubes containing ethylenediamine tetra acetic acid (EDTA) and blood samples were stored at $-80{ }^{\circ} \mathrm{C}$ untill the time of analysis. For isolation of DNA from blood samples in EDTA tubes obtained from individuals, GF-1 Blood DNA Extraction Kit (Vivantis®, Malaysia) was used.

Real time PCR (ABI 7500 FAST, USA) with hydrolysis based probe were used to determine the intronic FTO gene rs9939609 (T/A) SNPs. The individuals were classified into 3 groups according to the condition of having AA (homozygote genotype), AT (heterozygote genotype), TT genotypes (wild type genotype) based on the polymorphisms of rs9939609 of FTO gene. As a result of genetic analysis, the frequency of alleles detected in individuals was evaluated according to Hardy-Weinberg equilibrium and genotype frequencies were compared with expected frequencies according to Hardy-Weinberg equilibrium.

\section{Anthropometric measurements}

The body weights $(\mathrm{kg})$ were measured using the Tanita BC $545 \mathrm{~N}$ Inner Scan ${ }^{\mathrm{TM}}$ while the individuals were hungry and wearing light clothes. The height measurement $(\mathrm{cm})$ was performed by using stadiometer with standard protocols. The BMI was calculated with the "body weight/height ${ }^{2 \text { " }}\left(\mathrm{kg} / \mathrm{m}^{2}\right)$ equation, and classification of World Health Organization (WHO) according to BMI in adults was used[18].

\section{Statistical analysis}

The statistical evaluation of the data was performed by using the Statistical Package for the Social Sciences (SPSS, version: 22.0) statistical package program. Count (n), percentage (\%), arithmetic mean \pm standard deviation ( $\bar{x} \pm S D$ ), minimum(min)-maximum(max) values are given for the measured variables. The $\chi 2$ test was used to compare the general characteristics according to FTO gene (rs9939609) genotypes.

Visual and analytical methods (Kolmogorov-Smirnov/Shapiro-Wilk tests) were used to evaluate the convenience of data to normal distribution. According to the FTO gene genotypes, the individual's scores three factor eating questionnaire and serum leptin-ghrelin levels were compared with "One Way ANOVA" or "Kruskall-Wallis Variance Analysis". Sperman/Pearson correlation tests were used to evaluate the correlation between different parameters. $p<0.05$ was determined as the level of significance for all of the analyses. 


\section{Results}

When the frequency of FTO gene genotypes of individuals is evaluated, $19.0 \%$ of individuals were found to have AA genotype, $42.5 \%$ have AT and $38.5 \%$ have TT. Genotype distributions of the polymorphisms did not deviate from Hardy-Weinberg expectations (AA: 16.0\%; AT: 48.0\%; TT: 36.0\%) (p>0.05).

The general characteristics of individuals according to FTO gene genotypes are shown in Table 1. According to this; $68.4 \%$ of the individuals with AA genotype were female and $31.6 \%$ were male. Frequency of male and female individuals was $52.9 \%$ and $47.1 \%$ in those who have AT genotype and $55.8 \%$ and $44.2 \%$ in those who have TT genotype. The difference between gender frequency according to FTO gene genotypes was statistically significant $(p<0.05)$. $62.0 \%$ of the individuals were married, $35.5 \%$ were single and $2.5 \%$ were widowed/divorced and $62.5 \%$ were working in a job regularly. According to FTO gene genotypes, the difference between marital status and working status was not statistically significant $(p>0.05)$ (Table 1$)$.

When the average age (years) of the individuals is evaluated according to genotypes; The average age of individuals with AA genotype was $43.9 \pm 15.92 ; 39.0 \pm 13.24$ in individuals with AT genotype; $37.2 \pm 13.47$ in individuals with TT genotype. The difference between the average age of the individuals according to genotypes was not found to be statistically significant ( $p>0.05$ ) (Data not shown in the table). When the health histories of individuals are evaluated, it was determined that $28.0 \%$ of the individuals had a chronic disease diagnosed by a physician. The frequency of those with a chronic disease diagnosed by the physician was; $31.6 \%, 27.1 \%$ and $27.3 \%$ in those with AA, AT and TT genotypes, respectively $(p>0.05)$ (Table 1). $28.9 \%$ of the individuals in the AA genotype were obese, $26.3 \%$ were underweight, $23.7 \%$ were in normal weight and $21.1 \%$ were overweight. While $28.2 \%$ of the individuals with AT genotypes were overweight, $27.1 \%$ were obese, $27.1 \%$ were in normal weight and $17.6 \%$ were underweight. While $32.4 \%$ of the individuals in TT genotype were underweight, $23.4 \%$ were in normal weight, $23.4 \%$ were overweight and $20.8 \%$ were obese. According to FTO gene genotypes there was no statistically significant difference between BMI classification ( $p>0.05)$ (Table 1$)$.

\section{[Insert Table 1 about here.]}

Eating behaviour scores of the three-factor eating questionnaire according to the genders and the FTO gene genotypes of the individuals were shown in Table 2 . The cognitive restraint scores of males and females were $16.7 \pm 2.74$ and $16.1 \pm 2.34$, respectively. The difference between the cognitive restraint scores of individuals with different gender was statistically significant $(p<0.05)$. The uncontrolled eating score of the male individuals was $24.7 \pm 4.42$ while the average score for female individuals is $23.7 \pm 4.44$ $(p>0.05)$. When emotinal eating scores were evaluated, the mean score of the male individuals was $10.2 \pm 2.26$ and the mean score of female individuals was $8.5 \pm 2.84(p<0.05)$. There was no statistically significant difference between the total scores of the three-factor eating questionnaire of male and female individuals ( $p>0.05)$ (Table 2). 
When eating behaviour scores of individuals according to FTO gene genotypes were evaluated, there were no statistically significant difference between the cognitive restraint scores $(16.2 \pm 2.37,16.4 \pm 2.47$ and $16.5 \pm 2.77$, respectively) and the uncontrolled eating scores $(23.2 \pm 4.80 ; 24.4 \pm 4.41 ; 24.3 \pm 4.29$, respectively) ( $p>0.05)$. Although the emotional eating scores in individuals with TT genotype $(9.8 \pm 2.40)$ were significantly higher than that of those with AT and AA genotypes $(8.7 \pm 2.74,9.3 \pm 2.92)$, there was no statistically significant difference ( $p>0.05$ ). No significant difference was also found between the total scores of three-factor eating questionnaires among the different genotypes ( $p>0.05)$ (Table 2$)$.

\section{[Insert Table 2 about here.]}

The eating behaviour scores obtained by the three-factor eating questionnaire according to the FTO gene genotypes of the individuals with different gender were given in Table 3 According to this; of males, the cognitive restraint scores of those with AA, AT, TT genotypes as $16.5 \pm 1.78 ; 16.7 \pm 2.78 ; 16.8 \pm 2.96$, respectively and no statistically significant difference was found ( $p>0.05)$. Besides, there was no statistical difference between the cognitive restraint scores of females $(16.1 \pm 2.62 ; 16.0 \pm 2.05 ; 16.1 \pm 2.50$, respectively) $(p>0.05)$ (Table 3$)$.

When the uncontrolled eating scores were evaluated; the score of males with different genotypes was $24.0 \pm 5.21$ for AA genotype; $23.7 \pm 4.27$ for AT genotype and $23.7 \pm 4.49$ for TT genotype( $>0.05)$. Although the uncontrolled eating score of female individuals with AT genotype $(22.9 \pm 4.66)$ was less compared to those with AT $(24.4 \pm 4.41)$ and TT $(25.0 \pm 3.97)$ genotypes, there was no statistically significant difference $(p>0.05)$ (Table 3).

Among males, the score of emotinal eating of those with AA genotypes was $10.0 \pm 2.31$; of those with AT genotype was $10.2 \pm 2.40$ and of those with TT genotype was $10.4 \pm 2.13(p>0.05)$. Although females who have TT genotypes had higher scores of emotional eating than those with AT and TT genotypes, $(9.0 \pm 2.51,8.3 \pm 3.16,8.1 \pm 2.74$, respectively), this difference was not significant $(p>0.05)$ (Table 3$)$.

There was no significant difference in the total score of the three-factor eating questionnaire according to the genotypes for both male and female individuals in different genotypes ( $p>0.05)$ (Table 3 ).

\section{[Insert Table 3 about here.]}

Serum leptin levels of individuals with AA and AT and TT genotypes were respectively as follows; $4.4 \pm 5.42 \mathrm{ng} / \mathrm{mL}, 4.4 \pm 6.05 \mathrm{ng} / \mathrm{mL}$ and $3.4 \pm 6.0 \mathrm{ng} / \mathrm{mL}$ ( $p>0.05$ )(Table 3). Mean serum ghrelin levels $(\mathrm{pg} / \mathrm{mL})$ were found in individuals with AA, AT and TT genotype were found respectively as $146.7 \pm 124.4$, $114.9 \pm 107.58$ and $104.5 \pm 97.58 \mathrm{pg} / \mathrm{mL}(\mathrm{p}>0.05)$ (Data not shown in the table). The relationship between serum leptin $(\mathrm{ng} / \mathrm{mL})$ and ghrelin $(\mathrm{pg} / \mathrm{mL})$ levels and eating behaviour scores in individuals of different gender and genotype was evaluated in Table 4.

It was determined that there was a negative correlation between serum leptin levels and the cognitive restraint scores $(r:-0.210, p<0.05)$ and emotional eating scores $(r:-0.398, p<0.05)$. in all individuals The negative correlation between serum leptin level and three-factor eating questionnaire scores was 
determined and this relationship was statistically significant $(r:-0.220, p<0.05)$. There was no statistically significant correlation between serum leptin levels and uncontrolled eating scores in all individuals $(p>0.05)$ (Table 4).

There was no statistically significant relationship between the serum leptin levels and cognitive restraint scores, uncontrolled eating scores and emotional eating scores in males with AA, AT and TT genotypes $(p>0.05)$. However, while a negative correlation between serum leptin levels and the three-factor eating questionnaire total scores $(r:-0.713, p<0.05)$ was determined in males with $A A$ genotype, no relationship was found in individuals with AT and TT genotype ( $p>0.05)$ (Table 4).

No statistically significant relationship between the serum leptin levels, and the total and sub-dimension scores of the three-factor eating questionnaires in the females with AA, AT, and TT genotypes $(p>0.05)$ (Table 4).

There was no statistically significant relationship between serum ghrelin level and the score of threefactor eating questionnaire components in all individuals ( $p>0.05$ ). There was also no significant correlation between serum leptin levels and the score of three-factor eating questionnaire components in males with different genotypes ( $p>0.05$ ). In females, the relationship between serum ghrelin level and the three-factor eating questionnaire total score was negative in those with AT genotype $(r-0.365, p<0.05)$, positive in those with TT genotype $(r: 0.460 ; p<0.05)$. However, no statistically significant relationship was found in female individuals with AA genotype $(p<0.05)$ (Table 4).

\section{[Insert Table 4 about here.]}

\section{Discussion}

Obesity is one of the most important health problems of developed and developing countries. It shows that changes in eating behaviour and eating disorders are associated with increased obesity risk. However, how genetic loci affect eating behaviour and its effect on obesity are still popular among the individuals investigated. In this regard, the relationship of FTO gene which is thought to be related to obesity in many races, with eating behaviour, and the effect of gender and hormonal circulation on this relationship were evaluated in this study.

It has been reported that the FTO gene has an effect on obesity and BMI, especially in Caucasian populations, and variations occur in this gene are a risk factor for obesity[19]. Studies reported that each risk allele in the FTO gene increased the BMI by approximately $0.10-0.13 \mathrm{z}$ score, which corresponded to approximately $0.40-0.66 \mathrm{~kg} / \mathrm{m}^{2}$ or $1.3-2.1 \mathrm{~kg}$ body weight for an individual with a height of $1.80 \mathrm{~m} \mathrm{[20-}$ 22]. It has also been reported that each risk allele increases the risk of overweight and obesity by 1.2-1.3 times, respectively [20-22]. In another study, FTO gene rs9939609 SNPs of 194 Portuguese (Caucasian race) premenopausal female individuals ( 95 obese, 99 normal weight) were investigated, and the individuals with FTO rs9939609 risk allele was found to have 2.5 times more obesity risk [19]. In this study, although the frequency of obesity in individuals with FTO gene rs9939609 AA genotype seemed to 
be higher than in individuals with AT and TT genotype, this difference was not found to be statistically significant $(p>0.05)$ (Table 1). Thus, another FTO SNPs may be more effective on BMI than FTO rs9939609 polymorphism in the Turkish population. However, as an important finding in this study, AA genotype was found to be more frequent in females(Table 1). There are some studies in which FTO rs9939609 polymorphism is common in females and/or in women the risk allele was more likely to confer susceptibility to obesity [23-25]. This situation is often attributed to the high amount of fat tissue in females physiologically.

Since the FTO gene is highly expressed in the hypothalamic regions, it can change the eating behaviour by playing a role in the appetite and energy balance. In a study, it was found that the FTO gene rs1421085 and rs17817449 polymorphisms in overweight and obese individuals of the Caucasian race caused worse eating habits which are determined with the three-factor eating questionnaire, consumption of foods with the higher fat amount and more depressive symptoms [26]. It was concluded in one study that rs9939609 A allele was more common in individuals with eating disorders (AA + AT genotypes: $72.8 \%$ in the control group: $52.9 \%$ ), those individuals have higher emotional eating scores, and this may lead to obstructive eating behaviours [11]. Similarly, in a study on the Turkish population, melanocortin-4receptor gene (MC4R) mutations and FTO and neuromedin (NMB) gene mutations near this gene were found to be associated with eating behaviour phenotypes determined by a three-factor eating questionnaire[11]. Unlike other studies, it was determined that male and female individuals' cognitive restraint scores and emotinal eating scores were different in this study (Table 2, Table 3$)(p<0.05)$. However, a significant difference between the three-factor eating questionnaire sub-dimension scores and total scores of both male and female individuals in different genotypes was not determined $(p>0.05)$ (Table 2, Table 3). On the contrary to literature, it is thought that the reason for not being able to determine this relationship in this study was the fact that different measures were used to evaluate the eating disorders and there were racial differences in the present study. In addition, the situation of being diagnosed with depression of the individuals was investigated based on a personal declaration in this study. In one study, it was reported that the BMI of individuals with depression who had risk allele was $2.2 \%$ higher and increased the effect of FTO [27]. Therefore, it is considered that it will be useful to evaluate this situation by considering the depression status in the future studies.

Loss of eating control and/or eating disorders are often reported in overweight/obese children and adolescents [10]. In this regard, as a reason for different results related to eating behaviour, it is thought that the sample which is consisted of adults may be effective. In a study on 289 children and adolescents aged between 6 and 9 years, the loss of eating control in individuals with FTO gene rs9939609 AA/AT genotypes were found to be higher than participants with TT genotype (34.7\% and $18.2 \%$, respectively). In the same study, although the total energy intake of the individuals was not found to be different, the percentage of energy from fat was determined to be higher in individuals with AA/AT genotype [10]. In another study, it was reported that in children (9-10 years), the FTO gene rs9939609 genotypes were associated with being affected by the food-related television advertisements, followed by excessive nutrient/energy intake, and this relationship was still important even after BMI adjustment[28]. In a study to determine the underlying mechanism of the results of this study, it was found that the individuals who 
carried the FTO gene AA genotype have increased posterior cingulate, cuneus, precuneus and putamen activity in their brain compared to individuals with TT genotype[29]. In addition, it was reported that high BMI in individuals with genotype AA was associated with decreased activity in emotion (cingulate cortex) and impulse control regions (in frontal gyri and lentiform nucleus) for high calorie foods images. These results shed light on differences in impulse control and rewarding process in brain activities of individuals with different genotypes[29].

In this study, the effects of serum leptin and ghrelin levels on the eating behaviour scores of individuals with different genotypes were evaluated as a possible mechanism, with the exception of the mechanism suggested about impulse control and rewarding (Table 4). Leptin and ghrelin are closely related hormones with eating behaviour. Leptin is a hormone containing 167 amino acids and has a molecular weight of 16 kilodaltons. Leptin crosses the blood-brain barrier[30] and suppresses orexigenic neurons while stimulating anorexigenic neurons in the arcuate nucleus of the hypothalamus[31]. Accordingly, after leptin bound to the receptor, appetite-stimulating neuropeptide Y (NPY) and neuropeptides such as agouti-associated protein (AgRP) are suppressed, and anorexigenic hormones such as alpha-melanocytestimulating hormone, cocaine-amphetamine regulatory transcript, corticotropin-releasing hormone are stimulated [32,33]. Ghrelin is a peptide formed by the binding of n-octanoic acid to the third amino acid of the 28 amino acids. In humans, ghrelin increases food intake by peripheral and central mechanisms, including the stomach, hypothalamus and pituitary gland [34,35]. In this context, it has an appetizing effect and it realized its effect through NPY and AgRP in the arcuate nucleus of the hypothalamus [36]. It notices that genetic variations occurring in the loci of the FTO gene affects obesity as well as food intake by changing plasma leptin and ghrelin levels or expression levels [13, 14]. FTO rs9939609 A allele in premenopausal obese females was found to be associated with lower resting energy consumption and increased plasma leptin level [37].In a cross-sectional study of elderly individuals, the plasma levels of ghrelin which is a fasting hormone were found to be higher and the plasma levels of leptin which is a fullness hormone found to be were lower in those with FTO rs17817449 C allele, and thus FTO disrupted the endocrine balance [38]. In another study, independent from the body weight, FTO was found to be associated with a high fat diet-induced metabolic effect by changing the hypothalamic NFKB signal. Therefore, it has been reported that pharmacological modulation of FTO activity may have potential therapeutic benefits for increasing leptin sensitivity[39]. In studies investigating the association of ghrelin with FTO gene polymorphism, especially FTO or expression of this gene was determined to change the level of mRNA expression and especially to affect the level of acyl ghrelin[14, 40]. The analyses at the cellular level such as to support this reported that the expression level of FTO increased the ghrelin mRNA expression level and active ghrelin level following the display of nutrients with high-energy content, and there is a direct relationship between FTO risk alleles and ghrelin [40]. In another study, FTO has been reported to decrease postprandial fullness levels by causing changes in the level of acyl-ghrelin, which is an orexigenic hormone in homozygous individuals for the rs9939609 A allele, and this may be a mechanism that explains the relationship between FTO risk alleles and energy intake and obesity[20]

In the present study, different from the literature, there was no significant difference in serum leptin and ghrelin levels between the different genotypes in the individuals $(p>0.05)$. However, as expected, the total 
eating behaviour score was determined to be negatively associated with the serum leptin in females with AA genotype $(p<0.05)$, and positively associated with the serum ghrelin levels in males with TT genotype $(p<0.05)$. In this study, the reason for no differences between the levels of leptin and ghrelin in terms of genotypes may be the racial differences. In addition, it is considered useful to evaluate the messenger RNA (Mrna) expression levels of these peptides as well as the circulating levels of leptin and ghrelin according to genotypes in future studies.

\section{Conclusion}

As a result of this study, it was determined that eating behaviours in Turkish adults differed by gender rather than genotypes of FTO gene rs9939609. Moreover, gender is also important for circulating levels of leptin and ghrelin according to FTO rs9939609 polymorphism. So, this study sheds light on the importance of gender factor in the evaluation of eating behaviour of the FTO gene rs9939609 genotypes associated with serum leptin-ghrelin level.

This study is important in terms of evaluating the effect of FTO gene (rs9939609) polymorphism on eating behaviour in sociodemographic and biochemical perspective. As far as is known, this is the first study evaluating FTO gene (rs9939609) polymorphism and eating behaviour in Turkish adults ranged underweight to obese individuals. However, the present study has a number of limitations. First, a single locus of FTO gene (rs9939609) was examined in this study. Other locus of the FTO gene may have different effects on eating behaviour. So, the results of present study could not be generalized for whole FTO gene. Second, we didn't evaluate the mRNA expression levels of leptin and ghrelin related to FTO (rs9939609) genotypes. Alterations of mRNA expression levels of these peptides can play important role for eating behaviour. Third, the number of samples was relatively low compared to some large size population studies, but thus gave us the opportunity to compose homogeneous BMI groups that could affect eating behaviour. Nevertheless, it is considered that this study will light the way for other studies. It is believed that taking these situations into consideration would be useful in future studies.

\section{Abbreviations}

\section{AgRP}

Agouti-associated protein

\section{BMI}

Body mass index

\section{DNA}

Deoxyribonucleic acid

\section{EDTA}

Ethylenediamine tetra acetic acid

\section{ELISA}

Enzyme-linked immunosorbent assay

FTO 
Fat mass and obesity-associated

GWAS

Genome-wide association studies

mRNA

Messenger RNA

NMB

Neuromedin

NPY

neuropeptide $Y$

PCR

Polymerase chain reaction

SD

Standard Deviation

SNP

Single nucleotide polymorphism

SPSS

Statistical package for the social sciences

TFEQ-R18

Revised 18-item of the three-factor eating questionnaire

WHO

World Health Organization

\section{Declarations}

\section{Ethics approval and consent to participate}

In order to carry out this study, ethics committee approval (24074710-020/01 numbered and 02/13/2017 dated) was obtained from Gazi University Clinical Research Ethics Committee. Individuals have been explained the purpose and method of the study, and individuals who accepted to participate in the study were signed a voluntary consent form in accordance with the Helsinki Declaration (World Medical Association).

\section{Consent for publication}

Not applicable.

\section{Availability of data and materials}

We declare that the data supporting the conclusions of the article are fully described within the article, and the database is available from the first author (duyguturkozu@gazi.edu.tr) upon reasonable request.

\section{Funding}


This study was funded by grants from the Gazi University Projects of Scientific Investigation (BAP) (47/2017-05).

\section{Authors' contributions}

All authors designed and drafted the work or revised it critically for important intellectual content, and approved the final content off this manuscript.

\section{Acknowledgements}

Not applicable.

\section{Competing interests}

The authors declare that they have no competing interests.

\section{References}

1. Herrera BM, Keildson S, Lindgren CM. Genetics and epigenetics of obesity. Maturitas. 2011;69(1):419.

2. Maes HH, Neale MC, Eaves LJ. Genetic and environmental factors in relative body weight and human adiposity. Behavior genetics. 1997;27(4):325-51.

3. Rankinen T. Zuberi A, Chagnon YC, Weisnagel SJ, Argyropoulos G, Walts B, Perusse L, Bouchard C. The human obesity gene map: the. 2005:529-644.

4. Dai HJ, Wu JCY, Tsai RTH, Pan W-H, Hsu WL. T-HOD: a literature-based candidate gene database for hypertension, obesity and diabetes. Database. 2013;2013.

5. Loos R, Bouchard C. FTO: the first gene contributing to common forms of human obesity. Obes Rev. 2008;9(3):246-50.

6. Wang H, Dong S, Xu H, Qian J, Yang J. Genetic variants in FTO associated with metabolic syndrome: a meta- and gene-based analysis. Mol Biol Rep. 2012;39(5):5691-8.

7. Kim Y-J, Lee H-S, Kim YK, Park S, Kim J-M, Yun JH, et al. Association of metabolites with obesity and type 2 diabetes based on FTO genotype. PloS one. 2016;11(6).

8. Gu HF, Alvarsson A, Brismar K. The common FTO genetic polymorphism rs9939609 is associated with increased BMI in type 1 diabetes but not with diabetic nephropathy. Biomarker insights. 2010;5:BMI. S4599.

9. Müller TD, Greene BH, Bellodi L, Cavallini MC, Cellini E, Di Bella D, et al. Fat mass and obesityassociated gene (FTO) in eating disorders: evidence for association of the rs 9939609 obesity risk allele with bulimia nervosa and anorexia nervosa. Obes Facts. 2012;5(3):408-19.

10. Tanofsky-Kraff M, Han JC, Anandalingam K, Shomaker LB, Columbo KM, Wolkoff LE, et al. The FTO gene rs9939609 obesity-risk allele and loss of control over eating. The Am J Clin Nutr. 2009;90(6):1483-8. 
11. Castellini G, Franzago M, Bagnoli S, Lelli L, Balsamo M, Mancini M, et al. Fat mass and obesityassociated gene (FTO) is associated to eating disorders susceptibility and moderates the expression of psychopathological traits. PLoS One. 2017;12(3).

12. Speakman JR, Rance KA, Johnstone AM. Polymorphisms of the FTO gene are associated with variation in energy intake, but not energy expenditure. Obesity. 2008;16(8):1961-5.

13. Do R, Bailey SD, Desbiens K, Belisle A, Montpetit A, Bouchard C, et al. Genetic variants of FTO influence adiposity, insulin sensitivity, leptin levels, and resting metabolic rate in the Quebec Family Study. Diabetes. 2008;57(4):1147-50.

14. Karra E, O'Daly OG, Choudhury Al, Yousseif A, Millership S, Neary MT, et al. A link between FTO, ghrelin, and impaired brain food-cue responsivity. J Clin Invest. 2013;123(8):3539-51.

15. Stunkard AJ, Messick S. The three-factor eating questionnaire to measure dietary restraint, disinhibition and hunger. J Psychosom Res. 1985;29(1):71-83.

16. Karlsson J, Persson L-O, Sjöström L, Sullivan M. Psychometric properties and factor structure of the Three-Factor Eating Questionnaire (TFEQ) in obese men and women. Results from the Swedish Obese Subjects (SOS) study. Int J Obes Relat Metab Disord. 2000;24(12):1715-25.

17. Kıraç D, Kaspar E, Avcılar T, Çakır ÖK, Ulucan K, Kurtel H, et al. Obeziteyle ilişkili beslenme alışkanlıklarının araştırılmasında yeni bir yöntem "Üç faktörlü beslenme anketi”. Clinical Experimental Health Sciences. 2015;5(3):162-9.

18. World Health Organization (WHO). Global Database on Body Mass Index. 2019. Available from: http://apps.who.int/bmi/index.jsp. Accessed January 1, 2020.

19. Carlos FF, Silva-Nunes J, Flores O, Brito M, Doria G, Veiga L, et al. Association of FTO and PPARG polymorphisms with obesity in Portuguese women. Diabetes metabolic syndrome obesity: targets therapy. 2013;6:241.

20. Frayling TM, Timpson NJ, Weedon MN, Zeggini E, Freathy RM, Lindgren CM, et al. A common variant in the FTO gene is associated with body mass index and predisposes to childhood and adult obesity. Science. 2007;316(5826):889-94.

21. Scuteri A, Sanna S, Chen W-M, Uda M, Albai G, Strait J, et al. Genome-wide association scan shows genetic variants in the FTO gene are associated with obesity-related traits. PLoS genetics. 2007;3(7).

22. Andreasen CH, Stender-Petersen KL, Mogensen MS, Torekov SS, Wegner L, Andersen G, et al. Low physical activity accentuates the effect of the FTO rs9939609 polymorphism on body fat accumulation. Diabetes. 2008;57(1):95-101.

23. Marvelle AF, Lange LA, Qin L, Adair LS, Mohlke KL. Association of FTO with obesity-related traits in the Cebu Longitudinal Health and Nutrition Survey (CLHNS) Cohort. Diabetes. 2008;57(7):1987-91.

24. Ben Halima M, Kallel A, Baara A, Ben Wafi S, Sanhagi H, Slimane H, et al. The rs9939609 polymorphism in the fat mass and obesity associated (FTO) gene is associated with obesity in Tunisian population. Biomarkers. 2018;23(8):787-92.

25. Price RA, Li W-D, Zhao H. FTO gene SNPs associated with extreme obesity in cases, controls and extremely discordant sister pairs. BMC medical genetics. 2008;9(1):4. 
26. Harbron J, Van der Merwe L, Zaahl MG, Kotze MJ, Senekal M. Fat mass and obesity-associated (FTO) gene polymorphisms are associated with physical activity, food intake, eating behaviors, psychological health, and modeled change in body mass index in overweight/obese Caucasian adults. Nutrients. 2014;6(8):3130-52.

27. Rivera M, Locke AE, Corre T, Czamara D, Wolf C, Ching-Lopez A, et al. Interaction between the FTO gene, body mass index and depression: meta-analysis of 13701 individuals. The British Journal of Psychiatry. 2017;211(2):70-6.

28. Gilbert-Diamond D, Emond JA, Lansigan RK, Rapuano KM, Kelley WM, Heatherton TF, et al. Television food advertisement exposure and FTO rs9939609 genotype in relation to excess consumption in children. Int J Obes (Lond). 2017;41(1):23-9.

29. Wiemerslage L, Nilsson EK, Solstrand Dahlberg L, Ence-Eriksson F, Castillo S, Larsen AL, et al. An obesity-associated risk allele within the FTO gene affects human brain activity for areas important for emotion, impulse control and reward in response to food images. Eur J Neurosci. 2016;43(9):1173-80.

30. Hekimoğlu A. Leptin ve fızyopatolojik olaylardaki rolü. Dicle Tıp Dergisi. 2006;33(4):259-67.

31. Durak M, Akbıyık F, Demirpençe E. Obezite patogenezi. Hacettepe Tıp Dergisi. 2007;38:167-72.

32. Lenard N, Berthoud H. Central and peripheral regulation of food intake and physical activity: pathways and genes. Obesity. 2008;16:11-22.

33. Arora S, Anubhuti. Role of neuropeptides in appetite regulation and obesitya review. Neuropeptides. 2006;40(6):375401.

34. Wren A. Seal LJ, Cohen MA, Brynes AE, Frost GS, Murphy KG, Dhillo WS, Ghatei MA, Bloom SR. Ghrelin enhances appetite and increases food intake in humans. J Clin Endocrinol Metab. 2001;86:5992-5.

35. WrenAM S, AbbottCR D, SealLJ CM. Ghrelin causes hyperphagia and obesityinrats. Diabetes. 2001;50:2540-7.

36. Bilgin HM. Ghrelin; gündemdeki hormon. Dicle Tıp Dergisi. 2006;33(4):268-72.

37. Arrizabalaga M, Larrarte E, Margareto J, Maldonado-Martín S, Barrenechea L, Labayen I. Preliminary findings on the influence of FTO rs9939609 and MC4R rs17782313 polymorphisms on resting energy expenditure, leptin and thyrotropin levels in obese non-morbid premenopausal women. $J$ Physiol Biochem. 2014;70(1):255-62.

38. Benedict C, Axelsson T, Söderberg S, Larsson A, Ingelsson E, Lind L, et al. Fat mass and obesityassociated gene (FTO) is linked to higher plasma levels of the hunger hormone ghrelin and lower serum levels of the satiety hormone leptin in older adults. Diabetes. 2014;63(11):3955-9.

39. Tung YL, Gulati P, Liu C-H, Rimmington D, Dennis R, Ma M, et al. FTO is necessary for the induction of leptin resistance by high-fat feeding. Mol Metab. 2015;4(4):287-98.

40. Eissing L. FTO-associated obesity risk is linked to brain food responses via modulation of ghrelin levels. Nat Rev Endocrinol. 2013;9(10):564-5. 


\section{Tables}

Table 1 Evaluation of the general characteristics of individuals according to FTO gene genotypes *

\begin{tabular}{|c|c|c|c|c|c|c|}
\hline Characteristics & $\begin{array}{l}\text { AA Genotype } \\
\text { (n:38) } \\
n(\%)\end{array}$ & $\begin{array}{l}\text { AT Genotype } \\
\begin{array}{l}(n: 85) \\
n(\%)\end{array}\end{array}$ & $\begin{array}{c}\text { TT Genotype } \\
\text { (n:T7) } \\
\text { n(\%) }\end{array}$ & $\begin{array}{l}\text { Total } \\
\text { (n:200) } \\
\mathrm{n}(\%) \\
\end{array}$ & $x^{2}$ & p \\
\hline$\overline{\text { Gender }}$ & & & & & & \\
\hline $\begin{array}{l}\text { Vale } \\
\text { Female } \\
\end{array}$ & $\begin{array}{l}12(31.6) \\
26(68.4) \\
\end{array}$ & $\begin{array}{l}45(52.9) \\
40(47.1) \\
\end{array}$ & $\begin{array}{l}43(55.8) \\
34(44.2) \\
\end{array}$ & $\begin{array}{l}100(50.0) \\
100(50.0) \\
\end{array}$ & 6.504 & 0.039 \\
\hline Marital status & & & & & & \\
\hline $\begin{array}{l}\text { Married } \\
\text { Single } \\
\text { Widowed/Divorced } \\
\end{array}$ & $\begin{array}{c}27(71.1) \\
10(26.3) \\
1(2.6) \\
\end{array}$ & $\begin{array}{c}53(62.4) \\
30(35.3) \\
2(2.4) \\
\end{array}$ & $\begin{array}{c}44(57.1) \\
31(40.3) \\
2(2.6) \\
\end{array}$ & $\begin{array}{c}124(62.0) \\
71(35.5) \\
5(2.5) \\
\end{array}$ & 2.205 & 0.698 \\
\hline Working status & & & & & & \\
\hline $\begin{array}{l}\text { Employed } \\
\text { Jnemployed }\end{array}$ & $\begin{array}{l}21(55.3) \\
17(44.7) \\
\end{array}$ & $\begin{array}{l}50(58.8) \\
35(41.2) \\
\end{array}$ & $\begin{array}{l}54(70.1) \\
23(29.9) \\
\end{array}$ & $\begin{array}{l}125(62.5) \\
75(37.5) \\
\end{array}$ & 3.252 & 0.197 \\
\hline Chronic disease statu & & & & & & \\
\hline $\begin{array}{l}\text { Yes } \\
\text { No }\end{array}$ & $\begin{array}{l}12(31.6) \\
26(68.4) \\
\end{array}$ & $\begin{array}{l}23(27.1) \\
62(72.9) \\
\end{array}$ & $\begin{array}{l}21(27.3) \\
56(72.7) \\
\end{array}$ & $\begin{array}{c}56(28.0) \\
144(72.0) \\
\end{array}$ & 0.294 & 0.863 \\
\hline BMl classification & & & & & & \\
\hline $\begin{array}{l}\text { Underweight } \\
\text { '<18.50 kg/m²) } \\
\text { Normal }\end{array}$ & $10(26.3)$ & 15(17.6) & $25(32.4)$ & $25(25.0)$ & 5.437 & 0.489 \\
\hline $\begin{array}{l}\left(18.50-24.99 \mathrm{~kg} / \mathrm{m}^{2}\right) \\
\text { Overweight }\end{array}$ & $8(21.1)$ & $24(28.2)$ & $18(23.4)$ & $25(25.0)$ & & \\
\hline $\begin{array}{l}\left(25.00-29.99 \mathrm{~kg} / \mathrm{m}^{2}\right) \\
\text { Obese } \\
\text { (30 kg/m² and over) }\end{array}$ & $11(28.9)$ & $23(27.1)$ & $16(20.8)$ & $25(25.0)$ & & \\
\hline
\end{tabular}

* Column percentage is taken.

Chi-square test

Table 2 Eating behaviour scores according to gender and FTO gene genotypes of individuals* 


\begin{tabular}{|c|c|c|c|c|c|c|c|c|}
\hline \multirow[t]{2}{*}{ Variables } & \multicolumn{2}{|c|}{ Cognitive restraint score } & \multicolumn{2}{|c|}{$\begin{array}{l}\text { Uncontrolled } \\
\text { eating score } \\
\end{array}$} & \multicolumn{2}{|c|}{ Emotinal eating score } & \multicolumn{2}{|c|}{$\begin{array}{c}\text { Eating behaviour } \\
\text { total score } \\
\end{array}$} \\
\hline & $\overline{\mathrm{x}} \pm \mathrm{SD}$ & Min-Max & $\overline{\mathrm{X}} \pm \mathrm{SD}$ & Min-Max & $\overline{\mathrm{X}} \pm \mathrm{SD}$ & Min-Max & $\overline{\mathrm{x}} \pm S D$ & Min-Max \\
\hline \multicolumn{9}{|l|}{ Gender } \\
\hline Male & $16.7 \pm 2.74$ & $6.0-23.0$ & $23.7 \pm 4.44$ & $9.0-32.0$ & $10.2 \pm 2.26$ & $4.0-12.0$ & $50.8 \pm 7.53$ & $19.0-63.0$ \\
\hline Female & $16.1 \pm 2.34$ & $11.0-22.0$ & $24.5 \pm 4.42$ & 25.0 & $8.5 \pm 2.84$ & $3.0-12.0$ & $49.2 \pm 7.24$ & $32.0-62.0$ \\
\hline \multicolumn{9}{|c|}{$12.0-32.0$} \\
\hline & \multicolumn{2}{|c|}{ Z:-2.018; p:0.044 } & \multicolumn{2}{|c|}{ Z:-1.251; p:0.211 } & \multicolumn{2}{|c|}{$Z:-4.176 ; p<0.001$} & \multicolumn{2}{|c|}{ Z:-1.622; p:0.107 } \\
\hline \multicolumn{9}{|l|}{ Genotype } \\
\hline $\mathrm{AA}$ & $16.2 \pm 2.37$ & $12.0-21.0$ & $23.2 \pm 4.80$ & $12.0-32.0$ & $8.7 \pm 2.74$ & $3.0-12.0$ & $48.2 \pm 8.68$ & $32.0-61.0$ \\
\hline AT & $16.4 \pm 2.47$ & $12.0-23.0$ & $24.4 \pm 4.41$ & $13.0-31.0$ & $9.3 \pm 2.92$ & $3.0-12.0$ & $50.2 \pm 6.99$ & $31.0-63.0$ \\
\hline \multirow[t]{2}{*}{ TT } & $16.5 \pm 2.77$ & $6.0-22.0$ & $24.3 \pm 4.29$ & $9.0-32.0$ & $9.8 \pm 2.40$ & $3.0-12.0$ & $50.6 \pm 17.7$ & $19.0-63.0$ \\
\hline & \multicolumn{2}{|c|}{ Z:0.768; p:0.681 } & \multicolumn{2}{|c|}{ Z:1.777; p:0.411 } & \multicolumn{2}{|c|}{ Z:3.706; p:0.157 } & \multicolumn{2}{|c|}{ Z:1.842; p:0.398 } \\
\hline Total & $16.4 \pm 2.56$ & $6.0-23.0$ & $24.1 \pm 4.44$ & $9.0-32.0$ & $9.4 \pm 2.71$ & $3.0-12.0$ & $50.0 \pm 7.41$ & $19.0-63.0$ \\
\hline
\end{tabular}

*ANOVA test

Table 3 Eating behaviour scores according to FTO gene genotypes of individuals of different genders*

\begin{tabular}{|c|c|c|c|c|c|c|c|c|}
\hline & \multicolumn{2}{|c|}{ Cognitive restraint score } & \multicolumn{2}{|c|}{$\begin{array}{l}\text { Uncontrolled } \\
\text { eating score } \\
\end{array}$} & \multicolumn{2}{|c|}{ Emotinal eating score } & \multicolumn{2}{|c|}{$\begin{array}{c}\text { Eating behaviour } \\
\text { total score }\end{array}$} \\
\hline & $\overline{\mathrm{x}} \pm \mathrm{SD}$ & Min-Max & $\overline{\mathrm{x}} \pm S D$ & Min-Max & $\overline{\mathrm{x}} \pm \mathrm{SD}$ & Min-Max & $\overline{\mathrm{x}} \pm S D$ & Min-Max \\
\hline \multicolumn{9}{|c|}{ Male } \\
\hline AA & $16.5 \pm 1.78$ & $14.0-19.0$ & $24.0 \pm 5.21$ & $12.0-30.0$ & $10.0 \pm 2.31$ & $6.0-12.0$ & $50.6 \pm 8.48$ & $32.0-60.0$ \\
\hline AT & $16.7 \pm 2.78$ & $12.0-23.0$ & $23.7 \pm 4.27$ & $13.0-30.0$ & $10.2 \pm 2.40$ & $4.0-12.0$ & $50.6 \pm 7.20$ & $31.0-63.0$ \\
\hline \multirow[t]{2}{*}{ TT } & $16.8 \pm 2.96$ & $6.0-21.0$ & $23.7 \pm 4.49$ & $9.0-32.0$ & $10.4 \pm 2.13$ & $4.0-12.0$ & $51.0 \pm 7.76$ & $31.0-63.0$ \\
\hline & \multicolumn{2}{|c|}{ Z:0.913; p:0.633 } & \multicolumn{2}{|c|}{ Z:0.273; p:0.872 } & \multicolumn{2}{|c|}{ Z:0.146; p:0.929 } & \multicolumn{2}{|c|}{ Z:0.297; p:0.862 } \\
\hline \multicolumn{9}{|c|}{ Female } \\
\hline $\mathrm{AA}$ & $16.1 \pm 2.62$ & $12.0-21.0$ & $22.9 \pm 4.66$ & $12.0-32.0$ & $8.1 \pm 2.74$ & $3.0-12.0$ & $47.1 \pm 8.71$ & $32.0-61.0$ \\
\hline AT & $16.0 \pm 2.05$ & $12.0-20.0$ & $25.2 \pm 4.48$ & $15.0-31.0$ & $8.3 \pm 3.16$ & $3.0-12.0$ & $49.7 \pm 6.79$ & $34.0-60.0$ \\
\hline \multirow[t]{2}{*}{ TT } & $16.1 \pm 2.50$ & $11.0-22.0$ & $25.0 \pm 3.97$ & $17.0-32.0$ & $9.0 \pm 2.51$ & $3.0-12.0$ & $50.2 \pm 6.42$ & $32.0-62.0$ \\
\hline & \multicolumn{2}{|c|}{ Z:0.016; p:0.992 } & \multicolumn{2}{|c|}{ Z:4.909; p:0.086 } & \multicolumn{2}{|c|}{$\mathrm{Z}: 1.424 ; \mathrm{p}: 0.491$} & \multicolumn{2}{|c|}{$\mathrm{Z:2.207;} \mathrm{p:0.332}$} \\
\hline
\end{tabular}

*ANOVA test

Table 4. The relationship between serum leptin $(\mathrm{ng} / \mathrm{mL})$ and ghrelin $(\mathrm{pg} / \mathrm{mL})$ levels and eating behaviour scores in individuals with different gender and genotype* 


\begin{tabular}{|c|c|c|c|c|c|c|c|c|}
\hline \multirow[t]{2}{*}{ Variables } & \multicolumn{2}{|c|}{ Cognitive restraint score } & \multicolumn{2}{|c|}{ Uncontrolled eating score } & \multicolumn{2}{|c|}{ Emotional eating score } & \multicolumn{2}{|c|}{ Eating behaviour total score } \\
\hline & $\mathbf{r}$ & & $\mathbf{r}$ & & $\mathbf{r}$ & & $\mathbf{r}$ & \\
\hline \multicolumn{9}{|c|}{ Serum leptin } \\
\hline Male & -0.253 & 0.019 & -0.045 & 0.678 & -0.306 & 0.004 & -0.196 & 0.071 \\
\hline AA & -0.687 & 0.028 & -0.573 & 0.083 & -0.521 & 0.123 & -0.713 & 0.021 \\
\hline AT & 0.021 & 0.904 & 0.205 & 0.238 & -0.393 & 0.020 & 0.105 & 0.550 \\
\hline TT & -0.387 & 0.012 & -0.049 & 0.759 & -0.149 & 0.351 & -0.214 & 0.179 \\
\hline Female & -0.041 & 0.716 & -0.123 & 0.282 & -0.197 & 0.079 & -0.160 & 0.158 \\
\hline AA & -0.164 & 0.489 & -0.022 & 0.929 & -0.041 & 0.863 & -0.152 & 0.534 \\
\hline AT & 0.047 & 0.795 & -0.027 & 0.882 & -0.279 & 0.115 & -0.157 & 0.384 \\
\hline TT & -0.018 & 0.930 & -0.300 & 0.128 & -0.270 & 0.174 & -0.275 & 0.165 \\
\hline Total & -0.210 & 0.007 & -0.022 & 0.782 & -0.398 & 0.000 & -0.220 & 0.005 \\
\hline \multicolumn{9}{|c|}{ Serum ghrelin } \\
\hline Male & 0.135 & 0.216 & 0.138 & 0.206 & 0.019 & 0.861 & 0.140 & 0.198 \\
\hline $\mathrm{AA}$ & 0.252 & 0.483 & 0.378 & 0.281 & 0.247 & 0.492 & 0.354 & 0.316 \\
\hline AT & 0.005 & 0.978 & -0.082 & 0.639 & 0.019 & 0.912 & -0.067 & 0.703 \\
\hline TT & 0.267 & 0.092 & 0.184 & 0.248 & -0.028 & 0.864 & 0.204 & 0.201 \\
\hline Female & 0.243 & 0.030 & 0.082 & 0.473 & 0.035 & 0.758 & 0.130 & 0.255 \\
\hline $\mathrm{AA}$ & 0.401 & 0.080 & 0.297 & 0.217 & 0.423 & 0.063 & 0.402 & 0.088 \\
\hline AT & -0.037 & 0.840 & -0.282 & 0.112 & -0.232 & 0.193 & -0.365 & 0.037 \\
\hline TT & 0.364 & 0.062 & 0.283 & 0.153 & 0.251 & 0.206 & 0.460 & 0.016 \\
\hline Total & 0.123 & 0.115 & 0.125 & 0.109 & -0.140 & 0.073 & 0.068 & 0.382 \\
\hline
\end{tabular}

*Spearman correlation test 